Open Access

Res. Agric. Livest. Fish.

Review Article

Vol. 3, No. 1, April 2016: 27-35

\title{
FARMERS' PERCEPTION AND KNOWLEDGE OF CLIMATE CHANGE IN BANGLADESH - AN EMPIRICAL ANALYSIS
}

\section{Muntaha Rakib $^{1^{*}}$ and Shah Mohammad Hamza Anwar ${ }^{2}$}

'Department of Economics, Shahjalal University of Science and Technology, Sylhet, Bangladesh; '2Department of Economics, Metropolitan University, Sylhet, Bangladesh

*Corresponding author: Muntaha Rakib; E-mail: muntaha_rakib@yahoo.com

\section{ARTICLE INFOABSTRACT}

\section{Received}

12.03.2016

Accepted

16.04.2016

Online

30 April 2016

Key words

Climate change,

Agriculture,

Farmers,

Perception,

Bangladesh
The lack of sufficient knowledge about climate changes and the impact on agricultural production is an impediment to long term sustainable agriculture in most developing countries, including Bangladesh. This paper presents the results of an investigation to determine perception of farmers about changes in climate in Bangladesh. The study finds the determinants of farmers' perception on climate variability in different specifications of household characteristics. The sample was adult farmers with at least 20 years of farming experience in the area. Data was collected on perceptions about temperature changes and variability in precipitation over a 20 year period. The results indicated that more than $80 \%$ of farmers believe that temperature in the district had become warmer and over $90 \%$ were of the opinion that rainfall timing had changed, resulting in increased frequency of drought.

To cite this article: Rakib M and SMH Anwar, 2016. Farmers' perception and knowledge of climate change in Bangladesh - an empirical analysis. Res. Agric. Livest. Fish. 3 (1): 27-35. 


\section{INTRODUCTION}

Determining farmers' decision to adapt to and cope with shocks in one hand and for improving existing policies and to formulate new policies and supportive programs on the other hand; which types of farmers perceive that climate is changing is imperative to understand. Perception refers to the process of acquisition and understanding of information from one's environment (Maddox, 1995). Farmers have to perceive first that the climate has changed, and then identify useful adaptations and implement them (Maddison, 2006).Among the few researches on perception of farmers in Bangladesh, most of the studies focus on coastal area and very few of them on hill tracts. None of the studies analyzed the influencing factors of perception of agricultural farmers using econometric tools which is what the paper contributes. This paper however, covers all the geopolitical and agro-ecological zones in Bangladesh specially focusing on agricultural households, and is more country representative and is useful for policy implications.

Climate change is a major challenge to agricultural development and general livelihood conditions in Bangladesh. Living in a developing, densely populated flat land area, the poor people of Bangladesh are at severe risk due to climate change. Despite of the expanding service sector, agriculture which is heavily affected by climatic shocks, is the employment source of 46 percent of the total labor force (Labor Force Survey 2010) and approximately 17 percent of the country's GDP (Gross domestic product) (BBS 2013).It is forecasted that a rise of 1 meter sea level will inundate a 29,846 square kilometers area and will displace around 15 million people and to lose 15-17percent of its land in the coming decades (Akter 2009, IPCC 2001). These geographic and demographic characteristics make the country one of the most vulnerable due to climate change and other shocks.

\section{Literature review}

Most of the papers analyzing farmers' perception in Bangladesh revealed that farmers have the perception that climate is changing (Kamruzzaman, 2015, Rashid et al. 2014, Syeda and Nasser 2012) among which Kamruzzaman (2015) looked for the influencing factors of perception in Sylhet hilly region using tabular analysis. Level of education and access to extension services had significant association with their perceived cause of climate change (Kamruzzaman, 2015). Akanda and Howlader (2015) in a study on coastal farmers of Patuakhali District analyzed the correlates of farmers' perception where, education, farm size, annual family income, communication exposure and agricultural knowledge were positively correlated to perception while fatalism was negatively significant (Akanda and Howlader, 2015). Information of uncertainty of consequences of climate change influence risk perception (Moniruzzaman2013).

The studies find that both rainy season and cold season delays to start but ends early while mean duration of both seasons has been significantly reduced (Kamruzzaman, 2015, Rashid et al. 2014, Rakib et al. 2014). Farmers found areduction in overall rainfall and variation in wind speed, duration of strong wind. They felt the incidence of drought has been increased and flood has been decreased (Kamruzzaman, 2015, Rashid et al. 2014, Rakib et al. 2014). The extended summer periods with increasing average temperatures have resulted in decreased growth and yield of crops and increased pest infestations. Farmers also have perception that severe cold wave along with dense fog has been observed in Bangladesh, particularly in central and northern part, over couple of years (Sealand Baten 2011). Moniruzzaman (2013) in a different study revealed gradually decreasing knowledge and confidence levels of climate change from adult group to young groups. The results of the study support the claim that both knowledge and confidence levels will increase when people learn more about climate change. Changing of climate affects crop yield and cultivation especially the production of wheat (Syeda and Nasser 2012).

In a study on southern Khulna Rashid et al. (2014) found that, local people perceived changes in rainfall patterns and water-logging, resulting in delayed rice planting, decreased yield and damaged crops. The increased period during which river water is saline limits the scope of irrigation with river water (Rashid et al. 2014).Among several consequences of climate change, Seal and Baten (2011) found drainage congestion resulting from flood as the most dominating natural shock. In this study, the respondents of Sirajgonj identify riverbank erosion while inhabitant's of Shariatpur find salinity intrusion as the effect of climate change which is adversely affecting agriculture. 
Most of the other existing studies find that farmers are perceived about temperature increase and rainfall decrease (Gbetibouo 2009, Maddison 2006, Nhemachena and Hassan 2007). However, delayed rainfall, prolonged drought and extreme temperature are the most severe threats to agriculture in Bangladesh due to climate change (Bangladesh MoEF, 2005). BCAS (2009) finds erratic behavior of temperature and rainfall, extreme weather events and salinity are the most prominent indicators of climate change in Bangladesh. Adger et al. (2003) analyzed the annual average temperature and find that the country has experienced an increase of $0.40 \mathrm{C}$ to $0.80 \mathrm{C}$ temperature from 1900 to 2000 and until 2050 it is expected to increase by $1-20 \mathrm{C}$ more. Yu et al. (2010) analyzed sixteen global climate change model and simulated a positive trend of temperature increase from 2030s in Bangladesh while a higher intensity of precipitation in wet season and dryer winter which will intensify more droughts.

\section{Survey data}

The study utilized panel data collected through primary surveys of 800 agricultural households in rural Bangladesh in 2010 and 2012 that were administered by the International Food Policy Research Institute (IFPRI) and Data Analysis and Technical Assistance Limited (DATA), with additional inputs from the Center for Development Research (ZEF) in 31 out of 64 districts from all divisions across the seven agro-ecological zones which are categorized by Bangladesh Centre for Advanced Studies (BCAS).Therefore it is more representative with the whole set of major climatic shocks then the very few empirical past surveys in Bangladesh. Information was collected on demographic characteristics, physical asset, livestock and land ownership, crop management practices, access to credit and extension services, prior experience with climatic and non-climatic shocks, and perceptions about climate change. In 2012, additional information was collected on social and political capital and participation in groups by main male and female member of the household, coping mechanisms, adaptation strategies related to livestock; hence, the analysis involving these variables is for 2012 only. Note that, of the responding households used in the analysis, 89 percent were headed by men, and 11 percent were headed by women.

\section{Perception and knowledge of climate change}

Households were asked about their perceptions of temperature and rainfall changes and about overall climate change in the previous 20 years. Overall 90 percent households noticed that climate is changing from the last twenty years. Table 1 shows almost 88 percent of households reported being aware that rainfall was decreasing and approximately 86 percent noticed that temperatures were increasing. The three most cited changes were - more erratic rainfall, longer periods of drought and later onset of rains. This is consistent with the analysis of Thomas et al. (2013) using the baseline data, which is unsurprising given that the sample was a resurvey of Thomas's survey sites and that the follow-up survey was conducted only two years after the baseline.

Table 1. Households' perceptions of changes in rainfall and temperature in the past 20 years

\begin{tabular}{|lll|}
\hline Households' Perception & Rainfall & Temperature \\
\hline Share of households (\%) that $\ldots$ & & 86.0 \\
perceived an increase & 8.5 & 8.9 \\
perceived a decrease & 88.4 & 4.6 \\
perceived no change & 2.8 & 0.5 \\
did not know & 0.3 & 100.0 \\
Total & 100.0 & \\
\hline
\end{tabular}

Source: Calculated by author based on survey datain 2012. 
The farmers were asked about whether they perceive that climate is changing and if so, to mention the three most important changes they perceived. The most important changes they noticed and ranked as first are summarized in table 2 .

Table 2. Farmers' beliefs about the likely response to more extreme weather due to climate change

\begin{tabular}{|ll|}
\hline Most important change farmers perceived & Percent \\
\hline Rains have become more erratic & 71.25 \\
Rains come later & 8.42 \\
Longer periods of drought & 15.43 \\
Rains are heavier & 3.09 \\
Rains come earlier & 1.82 \\
Total & 100 \\
\hline
\end{tabular}

Source: Calculated by author based on survey data in 2012.

Among the other important indicators, longer periods of drought and more floods were noticed largely. They were also asked about whether they noticed any other changes and the result is shown in table 3. Other than rain and drought, change of starting time of season, level of water down, frequently cold wave and fogging and more floods etc. were noticed by the farmers.

Table 3. Noticed any other climatic changes

\begin{tabular}{|ll|}
\hline Any other changes farmers perceived & Percent \\
\hline Rains have become more erratic & 61.57 \\
Longer periods of drought & 19.02 \\
Average temperature changed & 9 \\
Rains are heavier & 3.21 \\
Starting time of season changed & 3.21 \\
Level of water is down & 2.83 \\
Frequently cold wave/fogging & 0.51 \\
More floods & 0.26 \\
Others & 0.39 \\
Total & 100 \\
\hline
\end{tabular}

Source: Calculated by author based on survey data in 2012

\section{Empirical approach}

In this section the factors associated with the perception that climate is changing by male and female heads are investigated. The paper starts with simple probit model estimated by maximum likelihood method to identify the correlates and subsequently check whether the strategies are taken as complement or substitute to each other by applying bivariate probit in appropriate cases.

A set of independent variables are chosen according to the relevance and on the basis of theory and previous works. The independent variables are gender of household head, years of schooling, work experience and age of household head, households' land ownership, physical assets measured in index using principal component analysis (PCA), livestock ownership in tropical livestock unit (TLU), access to extension and credit, group participation and information on social and political capitalof husbands and wives, experiences of climate change shocks and access to ICT by husbands and spouses. Even though the existing studies include physical capital, natural capital and livestock variables in their analysis (Deressa et al., 2010, 
Gbetibouo 2009, Nhemachena and Hassan 2007), access to these assets might be influenced by higher level of adaptation strategies and perception, which brings forth the endogeneity issue. Therefore, the asset variables, for instance physical capital, livestock, social and political capital are calculated as leave out village mean by considering that the people from same village are more similar to each other in their asset endowment than households of other villages. In calculating leave out village mean of a household's asset, the average of the rest of the households from the same village are taken into account dropping the household in question. Land ownership is defined as a binary variable with whether the household own more than 50 decimals of land which reflects functional land ownership in the perspective of Bangladesh (Quisumbing 2011, Hossain et al. 2007). Robustness of the results is checked by both including and excluding the asset variables in the model to minimize the simultaneity bias. Instead of using the social and political capital index, merely group participation of husbands and wives are also used to check the robustness of the results. To address possible heteroscedasticity, robust standard error is used throughout the paper. Besides, correlations among different independent variables are checked to avoid multicollinearity in the model.

\section{Farmers' perception of climate change}

It is interesting to know which types of farmers are likely to observe the climate change - an important issue to understand for practicing adaptation strategies. For this study, temperature increase and rainfall decrease are considered as the two measures of perceptions. To identify the correlates of farmers' perception of change in climate, the dependent variable is a binary variable that takes the value 1 if the head of household perceives that temperature is increasing or rainfall is decreasing from last twenty years and the value 0 otherwise.

Table 4 summarizes the marginal effects of probit regression in first two columns with asset variables calculated as leave out village mean. Results from Table 4 shows, female heads are more likely to notice rainfall decrease probably because it affects domestic water management, which is mainly women's duty in rural Bangladesh. Households which functionally own land and with physical and livestock assets especially when measured with leave out village mean, are more likely to be perceived about rainfall decrease probably because adequate rainfall is necessary for preparing land for cultivation, crop production and fodder for livestock. Gbetibouo (2009) found similar result for South Africa.

However, the perception of increasing temperature and decreasing rainfall are likely to be correlated to each other which demands seemingly unrelated biprobit model, the results of which are presented in table 5 . Column (1) and (2) investigates whether farmers have perception of climate change with asset variables calculated as leave out village mean while column (3) and (4) look at the same without leave out village mean.

Results from both of the tables (table 4 and 5) are consistent in terms of signs and statistical significance for most of the variables. Important finding is that, access to information and technology, political capital by male and group participation by female are positively and significantly correlated with the perception of both temperature and rainfall change. Probably female groups more emphasize the issue or alternatively they come in contact with different people which help them to develop their outlook about perception of climate change while, male who actively take part in politics and are more concerned about citizen rights and duty have better perception that the climate is changing. Surprisingly, access to credit and social capital of male and female are negatively correlated to perception either because the groups do not emphasize on this issue, or the households which have access to credit and other groups might already manage to overcome the problem of rainfall decrease by more irrigation for example. Surprisingly, education has no effect in influencing perception probably because farmers of survey sites has on an average 3 years of schooling which is very low to give rise the notion of climate change and variability. 
Table 4. Results of marginal effects of farmers' perception of change in the climate

\begin{tabular}{|c|c|c|c|c|}
\hline \multirow[b]{2}{*}{ Variable } & \multicolumn{4}{|c|}{ Probit } \\
\hline & $\begin{array}{l}\text { Temperature } \\
\text { increase } \\
\text { (1) }\end{array}$ & $\begin{array}{l}\text { Rainfall } \\
\text { decrease } \\
(2)\end{array}$ & $\begin{array}{l}\text { Temperature } \\
\text { increase } \\
\text { (3) }\end{array}$ & $\begin{array}{l}\text { Rainfall } \\
\text { decrease } \\
(4)\end{array}$ \\
\hline \multirow[t]{2}{*}{ Male headed household } & -0.012 & $-0.050^{*}$ & -0.011 & $-0.059^{* *}$ \\
\hline & $(0.040)$ & $(0.028)$ & $(0.043)$ & $(0.028)$ \\
\hline \multirow[t]{2}{*}{ Age of $\mathrm{HH}$ head } & 0.002 & 0.000 & 0.001 & 0.000 \\
\hline & $(0.001)$ & $(0.001)$ & $(0.001)$ & $(0.001)$ \\
\hline \multirow[t]{2}{*}{ Years of schooling of $\mathrm{HH}$ head } & 0.003 & -0.001 & 0.003 & -0.001 \\
\hline & $(0.003)$ & $(0.003)$ & $(0.003)$ & $(0.003)$ \\
\hline \multirow[t]{2}{*}{ Experience of $\mathrm{HH}$ head } & 0.000 & 0.000 & 0.001 & 0.000 \\
\hline & $(0.001)$ & $(0.001)$ & $(0.001)$ & $(0.001)$ \\
\hline \multirow[t]{2}{*}{ Whether $\mathrm{HH}$ functionally own land } & -0.029 & 0.022 & -0.006 & $0.038^{*}$ \\
\hline & $(0.027)$ & $(0.023)$ & $(0.026)$ & $(0.024)$ \\
\hline \multirow[t]{2}{*}{ Physical asset index (leave out village mean) } & 0.283 & $0.472^{* *}$ & - & - \\
\hline & $(0.247)$ & $(0.238)$ & & \\
\hline \multirow[t]{2}{*}{ Total livestock in TLU (leave out village mean) } & 0.041 & $0.102^{* \star *}$ & - & - \\
\hline & $(0.037)$ & $(0.033)$ & & \\
\hline \multirow[t]{2}{*}{ Physical asset index } & - & - & 0.024 & -0.047 \\
\hline & & & $(0.071)$ & $(0.070)$ \\
\hline \multirow[t]{2}{*}{ Total livestock in TLU } & - & - & -0.022 & 0.002 \\
\hline & & & $(0.014)$ & $(0.014)$ \\
\hline \multirow[t]{2}{*}{ Access to credit } & $-0.048^{*}$ & -0.004 & $-0.062^{\star *}$ & -0.024 \\
\hline & $(0.025)$ & $(0.024)$ & $(0.025)$ & $(0.023)$ \\
\hline \multirow[t]{2}{*}{ Access to extension } & -0.026 & 0.035 & -0.017 & $0.040^{*}$ \\
\hline & $(0.030)$ & $(0.024)$ & $(0.029)$ & $(0.024)$ \\
\hline \multirow[t]{2}{*}{ Affected by climatic shocks } & 0.024 & 0.022 & $0.049^{*}$ & 0.025 \\
\hline & $(0.026)$ & $(0.024)$ & $(0.027)$ & $(0.024)$ \\
\hline \multirow[t]{2}{*}{ Access to ICT by male } & $0.128^{* * *}$ & $0.076^{* *}$ & $0.163^{* * *}$ & $0.099^{* * *}$ \\
\hline & $(0.037)$ & $(0.036)$ & $(0.039)$ & $(0.036)$ \\
\hline \multirow[t]{2}{*}{ Access to ICT by female } & 0.104 & 0.078 & 0.020 & 0.071 \\
\hline & $(0.073)$ & $(0.073)$ & $(0.076)$ & $(0.073)$ \\
\hline \multirow[t]{2}{*}{ Group participation by male } & - & - & -0.036 & 0.016 \\
\hline & & & $(0.031)$ & $(0.025)$ \\
\hline \multirow[t]{2}{*}{ Group participation by female } & - & - & $0.064^{* *}$ & $0.070^{* * *}$ \\
\hline & & & $(0.028)$ & $(0.023)$ \\
\hline \multirow[t]{2}{*}{ Social capital of male (leave out village mean) } & $-0.514^{* *}$ & $-0.909^{* * *}$ & - & - \\
\hline & $(0.231)$ & $(0.197)$ & & \\
\hline \multirow[t]{2}{*}{ Social capital of female (leave out village mean) } & $-1.176^{* *}$ & -0.136 & - & - \\
\hline & $(0.499)$ & $(0.471)$ & & \\
\hline \multirow[t]{2}{*}{ Political capital of male (leave out village mean) } & $0.954^{\star \star *}$ & 0.065 & - & - \\
\hline & $(0.242)$ & $(0.202)$ & & \\
\hline \multirow[t]{2}{*}{ Political capital of female (leave out village mean) } & -0.495 & -0.597 & - & - \\
\hline & $(0.744)$ & $(0.612)$ & & \\
\hline Pseudo R-squared & 0.084 & 0.084 & 0.061 & 0.050 \\
\hline Total observations & 740 & 740 & 740 & 740 \\
\hline
\end{tabular}

Source: Calculated by authorfrom The Economics of Adaptation to Climate Change in Bangladesh follow-up Survey 2012. Notes: Robust standard errors are given in parentheses; ${ }^{* *} p<0.01,{ }^{* *} p<0.05,{ }^{*} p<0.1$. 
Table 5. Results of marginal effects of farmers' perception of change in the climate

\begin{tabular}{|c|c|c|c|c|}
\hline \multirow[b]{2}{*}{ Variable } & \multicolumn{4}{|c|}{ Seemingly unrelated biprobit } \\
\hline & $\begin{array}{l}\text { Temperature } \\
\text { increase } \\
\text { (1) }\end{array}$ & $\begin{array}{l}\text { Rainfall } \\
\text { decrease } \\
(2)\end{array}$ & $\begin{array}{l}\text { Temperature } \\
\text { increase } \\
\text { (3) }\end{array}$ & $\begin{array}{l}\text { Rainfall } \\
\text { decrease } \\
(4)\end{array}$ \\
\hline Male headed household & $\begin{array}{l}-0.058 \\
(0.207)\end{array}$ & $\begin{array}{l}-0.352 \\
(0.234)\end{array}$ & $\begin{array}{l}-0.055 \\
(0.217)\end{array}$ & $\begin{array}{l}-0.389^{*} \\
(0.236)\end{array}$ \\
\hline Age of $\mathrm{HH}$ head & $\begin{array}{l}0.008 \\
(0.006)\end{array}$ & $\begin{array}{l}0.000 \\
(0.006)\end{array}$ & $\begin{array}{l}0.005 \\
(0.005)\end{array}$ & $\begin{array}{l}-0.002 \\
(0.006)\end{array}$ \\
\hline Years of schooling of $\mathrm{HH}$ head & $\begin{array}{l}0.017 \\
(0.016)\end{array}$ & $\begin{array}{l}-0.010 \\
(0.018)\end{array}$ & $\begin{array}{l}0.016 \\
(0.016)\end{array}$ & $\begin{array}{l}-0.009 \\
(0.018)\end{array}$ \\
\hline Experience of $\mathrm{HH}$ head & $\begin{array}{l}0.002 \\
(0.006)\end{array}$ & $\begin{array}{l}-0.003 \\
(0.005)\end{array}$ & $\begin{array}{l}0.005 \\
(0.006)\end{array}$ & $\begin{array}{l}0.000 \\
(0.005)\end{array}$ \\
\hline Whether $\mathrm{HH}$ functionally own land & $\begin{array}{l}-0.144 \\
(0.136)\end{array}$ & $\begin{array}{l}0.135 \\
(0.135)\end{array}$ & $\begin{array}{l}-0.025 \\
(0.127)\end{array}$ & $\begin{array}{l}0.215^{*} \\
(0.133)\end{array}$ \\
\hline Physical asset index (leave out village mean) & $\begin{array}{l}1.386 \\
(1.251)\end{array}$ & $\begin{array}{l}2.748^{* *} \\
(1.414)\end{array}$ & - & - \\
\hline Total livestock in TLU (leave out village mean) & $\begin{array}{l}0.197 \\
(0.187)\end{array}$ & $\begin{array}{l}0.585^{\star * *} \\
(0.197)\end{array}$ & - & - \\
\hline Physical asset index & - & - & $\begin{array}{l}0.106 \\
(0.340)\end{array}$ & $\begin{array}{l}-0.260 \\
(0.390)\end{array}$ \\
\hline Total livestock in TLU & - & - & $\begin{array}{l}-0.102 \\
(0.065)\end{array}$ & $\begin{array}{l}0.010 \\
(0.080)\end{array}$ \\
\hline Access to credit & $\begin{array}{l}-0.258^{*} \\
(0.144)\end{array}$ & $\begin{array}{l}-0.017 \\
(0.141)\end{array}$ & $\begin{array}{l}-0.315^{\star *} \\
(0.141)\end{array}$ & $\begin{array}{l}-0.132 \\
(0.136)\end{array}$ \\
\hline Access to extension & $\begin{array}{l}-0.119 \\
(0.144)\end{array}$ & $\begin{array}{l}0.220 \\
(0.154)\end{array}$ & $\begin{array}{l}-0.079 \\
(0.138)\end{array}$ & $\begin{array}{l}0.247^{\star} \\
(0.145)\end{array}$ \\
\hline Affected by climatic shocks & $\begin{array}{l}0.118 \\
(0.124)\end{array}$ & $\begin{array}{l}0.124 \\
(0.130)\end{array}$ & $\begin{array}{l}0.232^{*} \\
(0.122)\end{array}$ & $\begin{array}{l}0.140 \\
(0.124)\end{array}$ \\
\hline Access to ICT by male & $\begin{array}{l}0.651^{* * *} \\
(0.190)\end{array}$ & $\begin{array}{l}0.455^{\star *} \\
(0.209)\end{array}$ & $\begin{array}{l}0.803^{\star * *} \\
(0.188)\end{array}$ & $\begin{array}{l}0.566^{* * *} \\
(0.199)\end{array}$ \\
\hline Access to ICT by female & $\begin{array}{l}0.516 \\
(0.358)\end{array}$ & $\begin{array}{l}0.469 \\
(0.432)\end{array}$ & $\begin{array}{l}0.083 \\
(0.367)\end{array}$ & $\begin{array}{l}0.397 \\
(0.405)\end{array}$ \\
\hline Group participation by male & - & - & $\begin{array}{l}-0.184 \\
(0.141)\end{array}$ & $\begin{array}{l}0.077 \\
(0.140)\end{array}$ \\
\hline Group participation by female & - & - & $\begin{array}{l}0.341^{*} \\
(0.178)\end{array}$ & $\begin{array}{l}0.449^{* *} \\
(0.188)\end{array}$ \\
\hline Social capital of male (leave out village mean) & $\begin{array}{l}-2.585^{\star *} \\
(1.170)\end{array}$ & $\begin{array}{l}-5.316^{\star \star \star} \\
(1.148)\end{array}$ & - & - \\
\hline Social capital of female (leave out village mean) & $\begin{array}{l}-6.000^{* *} \\
(2.529)\end{array}$ & $\begin{array}{l}-0.724 \\
(2.738)\end{array}$ & - & - \\
\hline Political capital of male (leave out village mean) & $\begin{array}{l}4.947^{* * *} \\
(1.263)\end{array}$ & $\begin{array}{l}0.418 \\
(1.150)\end{array}$ & - & - \\
\hline $\begin{array}{l}\text { Political capital of female (leave out village } \\
\text { mean) }\end{array}$ & $\begin{array}{l}-2.412 \\
(3.752)\end{array}$ & $\begin{array}{l}-3.380 \\
(3.475)\end{array}$ & - & - \\
\hline $\begin{array}{l}\text { Wald chi2(32) } 80.62^{\star \star \star} \\
\text { Total observations } 740\end{array}$ & & & & \\
\hline
\end{tabular}

Source: Calculated by authorfrom The Economics of Adaptation to Climate Change in Bangladesh follow-up Survey 2012. Note: Robust standard errors are given in parentheses; ${ }^{* * *} p<0.01,{ }^{* *} p<0.05,{ }^{*} p<0.1$. 


\section{CONCLUSIONS}

The study explores the detail empirical picture of farmers' perception of climate change and the level of their perception in agricultural households in Bangladesh. Results find that farmers of Bangladesh especially those with assets, access to credit, extension services and ICT, greater female participation in groups and more exposed to climate change shocks; are already perceived that climate is changing.Participation in social groups by women is particularly important in enhancing their perceptions of climate change which should be encouraged by Government with appropriate policy intake. Government policies should be initiated to improve household access to extension services and access to credit and information, which would improve and diversify farmers' knowledge of climate change and perception and thereby to improve their adaptation strategies. Improving opportunities for households to generate off-farm income could provide a further strategy in response to negative shocks. Political capital of male is important for farmers' perception rather than social capital which show the importance of knowledge diversification and dissemination. The study does not consist of gender disaggregated data of adaptation and coping. Future research using panel data and disaggregated by gender will increase the understanding of existing knowledge.

\section{ACKNOWLEDGEMENTS}

This work is supported by the Federal Ministry for Economic Cooperation and Development (BMZ), Germany under the project "Enhancing Women's Assets to Manage Risk under Climate Change: Potential for Group-Based Approaches". We express our sincerest gratitude to Joachim von Braun and Julia Anna Matz for comments and to ZEF, IFPRI, and DATA for collecting the data. Furthermore, we are grateful for comments and discussions of participants at various workshops and conferences. All errors are ours.

\section{REFERENCES}

1. Adger WN, S Huq, K Brown, D Conway and M Hulme, 2003. Adaptation to climate change in the developing world, Progress in Development Studies, 3: 179-195.

2. Akanda MGR and MS Howlader, 2015. Coastal Farmers' Perception of Climate Change Effects on Agriculture at Galachipaupazila under Patuakhali District of Bangladesh, Global Journal of Science Frontier Research: D, Agriculture and Veterinary, 15: Version 1.0.

3. Akter T, 2009. Climate Change and Flow of Environmental Displacement in Bangladesh, Unnayan Onneshan-The Innovators, www.unnayan.org

4. BBS, 2013. Bangladesh Bureau of Statistics, Statistics Division, Ministry of Planning, Government of the People's Republic of Bangladesh.

5. Bangladesh MoEF (Ministry of Environment and Forest), 2005. Bangladesh National Adaptation Program of Action (NAPA), Dhaka, Bangladesh.

6. BCAS (Bangladesh Center for Advanced Studies), 2009. Policy Study on the Probable Impacts of Climate Change on Poverty and Economic Growth and the Options of Coping with Adverse Effect of Climate Change in Bangladesh. Dhaka, Bangladesh: General Economics Division, Planning Commission; United Nations Development Program, Bangladesh.

7. Davis P and S Ali, 2014.Exploring Local Perceptions of Climate-Change Impact and Adaptation in Rural Bangladesh, IFPRI discussion paper 01322, January.

8. Deressa TT, C Ringler and RM Hassan, 2010. Factors Affecting the Choices of Coping Strategies for Climate Extremes: The Case of Farmers in the Nile Basin of Ethiopia, IFPRI Discussion Paper 01032, November, International Food Policy Research Institute, Washington, DC, USA.

9. Fankhauser S, 1998. The Costs of Adapting to Climate Change, GEF Working paper 16, Global Environment Facility, Washington, DC, USA.

10. Gbetibouo GA, 2009. Understanding farmers' perceptions and adaptations to climate change and variability: the case of the Limpopo Basin, South Africa. IFPRI Discussion Paper, 00849, International Food Policy Research Institute (IFPRI), Washington, DC, February. 
11. Hossain M, D Lewis,M LBose and A Chowdhury, 2007. Rice Research, Technological Progress, and Poverty: The Bangladesh Case. In Agricultural Research, Livelihoods, and Poverty: Studies of Economic and Social Impacts in Six Countries, edited by M. Adato and R. Meinzen-Dick. Baltimore: Johns Hopkins University Press.

12. IPCC (Intergovernmental Panel on Climate Change), 2001. Climate Change 2001.Overview of Impacts, Adaptation, andVulnerability to Climate Change. IPCC Third Assessment Report, Cambridge University Press. Downloaded from www.ipcc.ch.

13. Kamruzzaman M, 2015. Farmers' Perceptions on Climate Change: A Step toward Climate Change Adaptation in Sylhet Hilly Region, Universal Journal of Agricultural Research 3: 53-58.

14. Labor Force Survey, 2010. Bangladesh Bureau of Statistics, Statistics Division, Ministry of Planning, Government of the People's Republic of Bangladesh.

15. Maddison D, 2006. The perception of an adaptation to climate change in Africa. World Bank Policy Research Working Paper, 4308. The World Bank, Washington, DC.

16. Maddox GL, 1995. The Encyclopedia of Aginy.2nd edn. New York: Springer Publishing Company,Inc.

17. Moniruzzaman M, 2013. People's Perception on Climate Change and Variability: A Study of Sabrang Union, Teknaf, Cox's bazar, Bangladesh, ASA University Review 7 (2), July-December.

18. Nhemachena, C., R. M. Hassan, 2007. Micro-level analysis of farmers' adaptation to climate change in Southern Africa. IFPRI Discussion Paper, 714. International Food Policy Research Institute (IFPRI), Washington, DC: 30 .

19. Quisumbing A, 2011. Do Men and Women Accumulate Assets in Different Ways? Evidence from Rural Bangladesh. International Food Policy Research Institute (IFPRI) Discussion Paper No. 1096.

20. Rakib MA, M A Rahman, M S Akterand, MAH Bhuiyan, 2014. Climate change: Farmers Perception and Agricultural Activities. Herald Journal of Geography and Regional Planning, 3: 115 - 123 June.

21. Rashid MH, S Afroz, D Gaydon, A Muttaleb, P Poulton, C Rothand and Z Abedin, 2014. Climate Change Perception and Adaptation Options for Agriculture in Southern Khulna of Bangladesh, Applied Ecology and Environmental Sciences, 2: 25-31.

22. Santos I, I Sharif, HZ Rahman and H Zaman, 2011. How do the poor cope with shocks in Bangladesh? Evidence from survey data. Policy Research Working Paper 5810. The World Bank, South Asia Region, Social Protection Unit, September.

23. Seal $L$ and MA Baten, 2011. Reckoning Climate Change: Local Peoples' Perception on the Impacts of Climate Change in South-Central and Northern Bangladesh, The Unnayan Onneshan - The Innovators, Annual Report.

24. Syeda J. A. and M. Nasser2012. Farmers' Perception Regarding Climate Change and Crop Production, Especially for Wheat in Dinajpur District, Journal of Environmental Science \& Natural Resources, 5: 129 136.

25. Thomas TS, K Mainuddin , C Chiang, A Rahman, A Haque, N Islam, S Quasem and Y Sun, 2013. Agriculture and Adaptation in Bangladesh: Current and Projected Impacts of Climate Change. IFPRI Discussion Paper 01281, International Food Policy Research Institute, Washington, DC.

26. Yu WH, M Alam, A Hassan, A S.Khan, A C.Ruane,C Rosenzweig, DC Major and J Thurlow, 2010. Bangladesh - Climate change risks and food security in Bangladesh. World Bank, Washington DC. 